University for Business and Technology in Kosovo

UBT Knowledge Center

UBT International Conference

2012 UBT International Conference

Nov 2nd, 9:00 AM - Nov 3rd, 5:00 PM

\title{
Effects of Regional Trade Agreements on International Agricultural Trade
}

\author{
Biljana Ciglovska \\ International University of Struga, b.ciglovska@eust.edu.mk \\ Jeton Shaqiri \\ International University of Struga, j.shaqiri@eust.edu.mk
}

Follow this and additional works at: https://knowledgecenter.ubt-uni.net/conference

Part of the Business Commons

\section{Recommended Citation}

Ciglovska, Biljana and Shaqiri, Jeton, "Effects of Regional Trade Agreements on International Agricultural Trade" (2012). UBT International Conference. 34.

https://knowledgecenter.ubt-uni.net/conference/2012/all-events/34

This Event is brought to you for free and open access by the Publication and Journals at UBT Knowledge Center. It has been accepted for inclusion in UBT International Conference by an authorized administrator of UBT Knowledge Center. For more information, please contact knowledge.center@ubt-uni.net. 


\title{
Effects of Regional Trade Agreements on international agricultural trade
}

\author{
Biljana Ciglovska $^{90}$, Jeton Shaqiri ${ }^{91}$ \\ Faculty for Economic Sciences, International University of Struga, Macedonia \\ b.ciglovska@eust.edu.mk; j.shaqiri@eust.edu.mk
}

\begin{abstract}
Determining the effects of the trade liberalization is a complex problem of the modern theory of international trade. For that purpose we need to determine whether the maximum benefits from the trade for one country and the world in general, could be achieved when the foreign trade liberalization is implemented on non-discriminatory base (in terms of globalization) or when the foreign trade liberalization is implemented on discriminatory base id est., within the regional economic integration by introduction of safeguard measures towards third countries (regionalism).

Regionalization supporters affirm that the regional agreements promote more liberal trade and through the application of the rule "learning by doing" instigate the process of wider regional integration, which ultimately could result with global liberalization. Also, smaller group of countries with similar economic conditions (usually neighbor countries) could easily resolve their mutual trade problems through regional economic integration. According the regionalism supporters, in future within the WTO there will be three world negotiating blocks: the American, the European and the Asian trade block as carriers of the world economy.

The main purpose of this paper is by combination of theoretical and practical aspects to consider that the Regional Trade Agreements could promote the agricultural trade, by lowering and eliminating the rigorous procedures, restrictions and barriers in the international trade system. For that purpose will be used several methods that are usually used for economic analysis of the agricultural trade such as analytical, statistical, historical, comparative research method, method of observation, qualitative and quantitative method.
\end{abstract}

Key words: Regional trade agreements, WTO, agricultural trade, liberalization, barriers.

\section{Regional Free Trade Agreements}

The efforts for the international trade regionalization do not occure only in the recent dacedes. During sixties there were several attempts for making Regional Trade Agreements (RTAs), but they were unsuccessful. Even in the 1930 is noticed great fragmentation and separation of the world trade system into competitive blocks.

Regional Trade Agreements have played significant role in the political history. The first custom union was created in German y in $1834^{92}$ by 18 small countries. The base of RTA is the Most Favoured Nation clause (MFN), which was implemented for the first time by the Great Britain in the early years of the XIX century ${ }^{93}$.

After the First World War, the great efforts of the UK and the League of Nations for reintroducing the MFN clause in the regional trade agreemets are unsuccessful, whereupon the world is divided on two blocks, the English Commonwealth, Central Europe and others. With signing the General Agreement on Tariffs and Trade (GATT) in 1947, it was introduced the MFN

$90 \quad$ PhD Candidate - Teaching as sistant - International University of Struga

91 W.Handerson, The rise of German industrial power 1834-1914, University of California 1975, p.36

92 A. Yanai, The function of the MFN clause in the Global trading system, IDE APEC study center, working paper series 01/02 - No3. March 2002.

$93 \quad$ General Agreement on Tariffs and Trade GATT 1947 
principle in the article 1 of this Agreement, but at the same time was allowed and anticipated a concession from this clause in the article XXIV, where it was anticipated a possibility for concluding Regional Trade Agreements and it states “ $\boldsymbol{a}$ group of countries can form a free trade area or custom union, eliminating all barriers between contracting parties "94.

The conclusion of the RTA`s has its own advantages and disadvantages. One of the main advantages is the high level of liberalization and promotion of the trade between the signatory countries due to the removal of all obstacles and barriers that distort and limit the trade exchange, further higher level of collaboration between signatory countries and development of the intra-regional trade.

One of the main RTA`s disadvantages is discrimination, respectively placing other non signatory countries into unfavorable position because in the trade with these countries, the contracting parties do not apply the mutual benefits and concessions that they otherwise apply within the agreement.

The rapid growth of RTAs could lead to attaining an opposite process of globalization that is the main goal of the WTO and other international organizations and creating two or three blocks that will reciprocally fight and compete for the world market, instead of drawing together and collaborating.

During the period 1947-1994 within the GATT are concluded 109 RTAs, for which the great initiators are the USA ${ }^{95}$. In the period 1980-1990, the share of intra-regional trade in the total trade is increasing especially in the East Asia from $33.8 \%$ to $38.4 \%$, in the North America from $31.5 \%$ to $37.3 \%$, in the EU from $52.4 \%$ to $63.4 \%$. In addition there are four factors that influenced to the intensive regionalization: the European integration, the USA strategy, the develop ment of Canada and the changed attitude towards the developing countries' trade.

The pioneer of EU - the European Economic Community (EEC) created the Common Agricultural Policy (CAP) in 1960 in order to regulate the agricultural market. The main goal was improving the farmers income and securing the necessary supply for consumers.

CAP was promoting free inner trade through offering preferences to the member countries, wherewith the intra-regional import increased from $28 \%$ in 1962 to $70 \%$ in $1990^{96}$. The creation of CAP has leaded the EU a step forward from other regions regarding the complete liberalization of agricultural trade. In 1987 was accepted the initiative for creating a common market and it entered into force in 1992. The ambitious plan was turning the free trade area into one common market. As a result of these integrating processes of the European countries, the intra and extra regional trade was developing and liberalizing.

In 1960 was established the European Free Trade Area (EFTA) with a view to liberalize the trade between the member states and provide free trade flows. In the following years, EFTA concluded number of additional bilateral agreements for trade liberalization in order to increase the volume of the trade which leaded to significant increase of the intra-regional trade. Regarding the agricultural products, the member states still keep their national autonomy and allow only minimal liberalization of the reciprocally trade with agricultural products.

$94 \quad$ S.Sheffield, Agriculture, GATT and Regional Trade Agreements, Economic Research Service USDA, p.87

95 M.E. Burfisher, E.A.Jones, RTA's and Agricultural trade: A retrospective assessment, Market and Trade Economics Division, Economic Research Service, U.S. Department of Agriculture. Agricultural Economic Report No. 771. November 1998, p. 28

Ibid. 
In 1983, Australia and New Zealand established close economic relations (CER) that resulted with $10 \%{ }^{97}$ increased mutual agricultural import in 5 years.

The Free Trade Agreement between USA and Canada was concluded in 1989 (NAFTA), and therefore the intro -regional trade in agricultural products significantly increased. In 1994 the Agreement was also signed by Mexico that already has some concessions in the trade with USA according to the General System of Preferences (GSP). But in any case the Agreement is increasing the volume of intra-regional trade.

In 1991 after several tariffs reductions in both countries, it was created the economic union between Brazil and Argentina (MERCOSUR). This liberalization leaded to enrichment of the agriculture structure and changes in the agricultural products trade flows. The share of agricultural trade within the MERCOSUR is doubling.

After the sharp fall in the beginning of the nineties, this share is increasing again with the MERCOSUR enlargement and incorporation of Paraguay and Uruguay in 1994. With this composition, the intra-regional trade during the period of $1994-1998$ is doubling and the import from third countries is lowering for $2 / 3$, which presents the effect of trade diversion ${ }^{98}$.

The Association of the Southeast Asian Nations (ASEAN) ${ }^{99}$ was primarly formed in 1967 for political and military purposes, and in 1991 it officialy launched the Free Trade Area (AFTA) ${ }^{100}$. The member countries had weak motives for mutual agricultural import because of their similar production rules. In fact the trade participation within the AFTA shows that, in the last 15 years the member countries are becoming less and less dependent on each other about assurance of the domestic agricultural import.

The analysis of the trade share shows that, the agricultural trade of the RTA`s member countries, is becoming dominant within the intra-regional trade. But, in the AFTA case the intra-regional trade is not increasing as a result of this Agreement, because the members have competitive and not complementary advantages in the agricultural production.

In 1989 was established the Forum for Asia-Pacific Economic Cooperation (APEC) in Cambera, Australia in order facilitating the tarde between the member countries ${ }^{101 . ~ A p e c ~ i s ~ a ~ n e t w o r k ~ o f ~ s p e c i a l ~ c o u n t r i e s ~ a n d ~ s e v e r a l ~ r e g i o n a l ~ f r e e ~ t r a d e ~ a g r e e m e n t s ~}$ (NAFTA, AFTA, CER), whose main purpose is free trade with agricultural products until 2010 and 2020 for developing countries. The intra regional trade within the APEC notes increase, because the member countries have complementary production and consumer model in agriculture.

In 1993 is established the Central European Free Trade Agreement (CEFTA) with one main purpose like all other free trade zones. Regarding the agricultural trade liberalization, the member countries reciprocally obligate to allow tariff concessions through agreed schemes for liberalization and additional concessions. Beside that, every member state has right to implement its own agricultural policy and undertake protective measures if needed.

It is very important to point out that, during the function of all RTA`s there is a big number of additional Free Trade Agreements or Preferential Trade Agreements, that all those Free Trade Areas has conclude with other countries on a bilateral level, in order facilitating and further development of their mutual trade.

\footnotetext{
97 W.Watson, V.Do, Economic Analysis of Regional Trade Agreements, p.9

98 ASEAN Founders are the following countries: Thailand, Malaysia, Phillippines, Singapore and Indonesia, but the following countries acompanied the ASEAN like, Brunei, Cambodia,Laos, Mianmar, and Vietman. .

99 Member countries of AFTA are: Brunei, Indonesia, Malaysia, Phillippines, Singapore, Thailand, Vietnam, Laos, Mianmar and Cambodia.

100 APEC members: Australia, Brunei, Canada, Chile, China, Hong Kong, Indonesia, Japan, Malaysia, Mexico, New Zealand, New Guinea, Philippines, Singapore, South Korea, Taiwan, Thailand, USA, Russia, Peru and Vietnam.

$101 \quad$ Mary E. Burfisher and Elizabeth A. Jones, 1998
} 
The econometric analysis show that, not all Regional Trade Areas have positiv influence on the economic welfare, as a result of change in agricultural models ${ }^{102}$. Anyway, the NAFTA, MERCOSUR, ASEAN-AFTA has lead to increase of agricultural products between the partners and with countries and also with countries that are not members of these agreements.

\section{The influence of certain Regional Trade Agreements on trade with agricultural goods}

The international trade is increasingly regulated with regional and bilateral trade agreements, because by them, the countries are seeing a possibility for lowering and eliminating the rigorous procedures, restrictions and barriers in the international reg ulations, particularly with respect to the agricultural trade. As a result of the enormous number of regional agreements, the international organizations usually analyze them in order to determine what is their influence on the international trade flows. For that purpose at this point will be discussed the impact of different Regional Trade Agreements such as AFTA, COMESA and MERCOSUR, signed between group of developing countries on their agricultural sectors and their agricultural trade.

AFTA is a Free Trade Area of the ASEAN countries and has 10 member countries that have small share in the world trade, around $5 \%^{103}$. The member countries are liberalizing the mutual trade through gradual reduction of tariff rates for all products. But, countries from this area have opportunity to exclude some products from the list of Common preferential tariffs, according which they are reciprocally importing products from their markets under special conditions. Many AFTA countries do not open their markets for some sensitive agriclutural goods (such as the rice and sugar). The implementaton of AFTA starts in 1994 and it is completely implemented in 2001. The complete implementation significantly increases the agricultural trade between member countries.

The analyses made by Korinek and Menaltos, show that when the Agreement was fully implemented, the AFTA countries export lower volume of products outside the region and it is $25 \%$ lower compared to the period before the implementation of the Agreement ${ }^{104}$.

Concerning the import, member countries of AFTA import greather volume of products from the third countires that are not members of the free trade area. It points out the positive efect of the RTAs on import (trade creation). Regarding the produ ction of agricultural goods the AFTA member countries have comparative advantage in the export of vegetable oils, rice, fish and shell-fish, cocoa, spices, canned fruit and various grain products.

The AFTA member countries during their functioning are losing their comparative advantage in the production of sugar, but they are increasing the comparative advantage in the production and export of margarine.

According to the data in the Table 1. the share of agricultural export from AFTA countries in the total trade with agricultural goods notes decrease in the period between 1991-2005 from 9.1\% to $5.5 \%{ }^{105}$. The same is due to the industrialization process of the ASEAN member countries. But, in 2010 there is significant growth of agricultural export of 12.6\%. Regarding the intra regional agricultural trade, according to the data in the Table 2, before signing the Agreement the intra-AFTA trade with agricultural products accounts for $17 \%$ of the total intra regional trade, but after signing the Agreement the share of intra-AFTA agricultural trade in the total agricultural export from AFTA is increased on $23 \%$.

102 J.Korinek, M.Melatos, Trade impacts of selcted Regional Trade Agreements in Agriculture, OECD Trade Policy Working Papers No. 87, OECD, France, 2009, p.4

103 J.Korinek, M.Melatos, Op.cit., OECD Trade Policy Working Papers No. 87, OECD, France, 2009, p.15

$104 \quad$ Ibid.p. 12

$105 \quad$ Ibid.p.19 
For further liberalization and growth of agricultural trade, the ASEAN countries have concluded additional bilateral agreemen ts with the two increasing markets from this region China and India, and with those agreements is anticipated reduction of tariff rates.The fully implementation of the Agreement with China (CAFTA) started from 01.01.2010. These countries intensively trade agricultural goods with China and India, whereupon 9\% of the AFTA`s agricultural trade is realized with China and 4\% with India ${ }^{106}$

Table 1. Structure of Agricultural export of selected RTAs

\begin{tabular}{|c|c|c|c|c|c|}
\hline & $\%$ & 1991 & 2001 & 2005 & 2010 \\
\hline World total & & 8.2 & 7.0 & 6.3 & - \\
\hline AFTA & & 9.1 & 5.4 & 5.5 & 12.6 \\
\hline COMESA & & n.a. & 41.7 & 21.0 & \\
\hline $\mathbf{E U}$ & & 7.9 & 8.1 & 7.9 & 15.4 \\
\hline MERCOS UR & & 26.8 & 33.0 & 32.4 & 39.9 \\
\hline NAFTA & & 10.1 & 7.2 & 6.8 & 11.2 \\
\hline
\end{tabular}

Source: World Integrated Trade Solution (WITS).

Table 2. Intra regional trade as a percentage of total trade

\begin{tabular}{|c|c|c|c|c|c|}
\hline & $\%$ & 1981 & 1991 & 2001 & 2005 \\
\hline \multicolumn{6}{|l|}{ AFTA } \\
\hline Total & & 0.18 & 0.21 & 0.23 & 0.26 \\
\hline Agriculture & & 0.17 & 0.18 & 0.25 & 0.23 \\
\hline \multicolumn{6}{|l|}{ COMESA } \\
\hline Total & & - & - & 0.11 & 0.07 \\
\hline Agriculture & & - & - & 0.13 & 0.15 \\
\hline \multicolumn{6}{|l|}{$\mathbf{E U}$} \\
\hline Total & & 0.57 & 0.66 & 0.66 & 0.65 \\
\hline Agriculture & & 0.65 & 0.75 & 0.74 & 0.75 \\
\hline \multicolumn{6}{|l|}{ MERCOS UR } \\
\hline Total & & 0.10 & 0.11 & 0.17 & 0.13 \\
\hline Agriculture & & 0.05 & 0.09 & 0.11 & 0.05 \\
\hline \multicolumn{6}{|l|}{ NAFTA } \\
\hline Total & & 0.34 & 0.41 & 0.55 & 056 \\
\hline Agriculture & & 0.17 & 0.29 & 0.44 & 0.46 \\
\hline
\end{tabular}

Извор: World Integrated Trade Solution (WITS).

106 J. Wanjiku, M.Ogada, P.Guthiga, J. Karugia, S.Massawe, J.Wambua, Exploiting opprtunities in intra-regional trade in food staples in COMESA region, 2012, p.14 
COMESA is a Common Market of the East and South Africa, created in 1993 from 19 signatory countries in order to become free trade area, that is achieved in 2000 when the 9 founder countries eliminated the tariffs for all goods that are coming from the member countries. Periodically within 6 months the member countries have right to implement safeguard measures (tariffs) for the import of some sensitive agricultural products. The countries of this area compared to the AFTA and MERCOSUR members have different level of economic development (least developed and developing countries).

Intra COMESA trade with agricultural goods is with low volume, or $13 \%$ from the total trade in 2001 and $15 \%$ in 2005 . The intra COMESA trade mostly takes plase between the neighbour countries, because the member countries are heavily accessible in georaphic terms, they have underdeveloped infrastructure and it takes long time to complete the customs procedures for importing goods. Generally there has been an increasing trend in intra-COMESA total trade and agricultural trade from year 2003 until the recent slowdown in 2008 and 2009. Agricultural trade is an important component of the total trade in the COMESA region, accounting for about a third of the total trade. Trade statistics for year 2009 indicate that agricultural tra de accounts for about 32 percent of the total intra-COMESA trade ${ }^{107}$.

The COMESA member countries mostly trade between them due to the duty-free access to their markets, but nevertheless the trade creation effect is lower compared to the RTAs, AFTA and MERCOSUR. The biggest problem is the transport of the goods that needs 2-3 weeks to transport goods between the member countries. It is neccessary in this region to improve the economic and infrastructural conditions, to increase the productivity, to provide physical access to the members`markets, easier access to loans and so on.

MERCOSUR is a common market of the South America established in 1991 by Argentina and Brazil, and today it has 4 member countries. The main purpose is providing duty-free access for all goods to the members markets, except for automobiles and sugar, that are subject to bilateral regimes. In 1994 MERCOSUR is becoming a custom union and applies uniform custom tariff in the trade with third countries. Within MERCOSUR 90\% of the total trade is taking place between Brazil and Argentina. The agriculture has a large and growing share in the members` export, which accounts for $32 \%$ of the MERCOSUR export.

Brazil and Argentina have comparative advantages in the export of very similar agricultural goods, and therefore they mutually trade between those agricultural goods for which they do not have comparative advantages ${ }^{108}$. This trend is due to the duty-free access that the agricultural goods have on the members markets and the protection they have as a result of the common foreign custom tariff and high barriers that treir products are facing with on their main export markets.

According to the data in Table 2, we can see that during the period 2001-2005 the share of intra-MERCOSUR trade in the total trade is decreasing from $17 \%$ to $13 \%$ respectively, and the same happens with the intra-MERCOSUR trade in agricultural goods, which during the same period lowers its share in the total MERCOSUR trade from $11 \%$ to $5 \%$. Significant barrier in the intraMERCOSUR trade is the double duty charging on the import from third countries. Namely, when some good is imported in one of the member countries, for reexporting it in another member country or for reexporting becouse of the necessary transformation of the good, the same will be double charged while entering the other member country. For that purpose it is strictly respected the rule for goods origin.

The elaborated RTAs according to the analyses of the Korinek and Melatos, show trade creation effect in the trade with agricultural goods in the adequate regions. Also, it can be concluded that the level of integration within the Agreement has great importance for the level of trade creation. Membership in the RTA on its merits is not enough to overcome some of the physical

107 J.Korinek, M.Melatos, Op.cit., OECD Trade Policy Working Papers No. 87, OECD, France, 2009 , p.29

108 This number deviates from the results derived from Eurobarometer due to differing definitions. 
and economic barriers in the trade. That is also case with the member countries of COMESA that should improve the basic infrastructural and economic conditions in order to realize the benefits from the RTAs. The trade costs such as, transport and logistic costs in great level influence to the trade flows of agricultural goods. Historical and traditional economic relatio ns are also important determinants of trade flows. But, one issue that still remains unsolved within the RTAs is that, some of the trade barriers further continue to exist and apply within the RTAs, such as the subsidies and some non tariff barriers.

Therefore, the existance of the numerous RTAs and numerous Bilateral Agreements resulting from them, impose the issue for discussion, Whether the membership in RTA lowers the interest for multilateral negtiations and liberalization? This new trend of regionalism has proved as less harmful for the third countries that are not members of the RTA and less harmful for the whole international trade system, because with the new RTAs in the process of trade liberalization are included more products and instruments compared to the previous Agreements, that increase the level of integration.

Although there are criticisms and accusations towards RTAs that they are established on discriminatory base, that they violate the MFN principal and they are to the detriment of the third countries that are not members, removing them from the international trade flows, the practice and the data present opposite results, where it is obvious that, RTAs in much great extent lead to development and increased extra-regional trade in comparison with the intra-regional trade.

\section{CONCLUSION}

RTAs can improve the functioning of the International Trade System, through implementing a system of gradual trade liberalization. Countries are trading in much greather extent when their relations are based on RTA, but however these agreements can not replace the multilateral liberalization, because some countries do not have basic and natural preconditions for agricultural trade development and utilization of benefits that regional trade liberalization offers.

The unfinished Doha Round of negotiations and the uncertainity of the same, still more contribute for increasing the numb er of RTAs. Therefore we should not underestimate and neglect the multilateral liberalization, because there is a risk for trade blocks created with the RTAs to become counterproductive.

\section{REFRENCES :}

1. G.Benson, M.Marchant, P.Rosson, US Agriculture and International trade, Texas Agriculture Extension Service, The Texas A\&M University System, RM6-4.0 4-98,

2. GATT(1986), The Text of The General Agreement on Tariffs and Trade ; Geneva,

3. H.Cabalu, C.Alfonso, Does AFTA create or divert trade?, University of Technology and Asian Development bank,

4. J.Niemi, (2001) The effects of trade liberalization on ASEAN agricultural commodity export to the EU, 77th EAAE Seminar / NJF Seminar No. 325,Helsinki

5. Eugui, V, Ottawa D., QUNO, (2003) Regional and Bilateral Agreements and a TRIPS-Plus World: The Free Trade Area of the Americas (FTAA);

6. W.Watson, V.Do, Economic Analysis of Regional Trade Agreements 
7. J. Wanjiku, M.Ogada, P.Guthiga, J. Karugia, S.Massawe, J.Wambua,(2012) Exploiting opprtunities in intra-regional trade in food staples in COMESA region,

8. J.Korinek, M.Melatos,(2009) Trade impacts of selcted Regional Trade Agreements in Agriculture, OECD Trade Policy Working Papers No. 87, OECD, France,

9. M.E. Burfisher, E.A.Jones,(1998) RTA`s and Agricultural trade: A retrospective assessment, Market and Trade Economics Division, Economic Research Service, U.S. Department of Agriculture. Agricultural Economic Report No. 771. November

10. S.Sheffield, Agriculture, GATT and Regional Trade Agreements, Economic Research Service USDA

11. W.Handerson, (1975)The rise of German industrial power 1834-1914, University of California

12. A. Yanai, The function of the MFN clause in the Global trading system, IDE APEC study center, working paper series 01/02 - No3 